\title{
Gynecological Cancer Awareness: Reproductive Age and Postmenopausal Women
}

\author{
Jinekolojik Kanser Farkındalı̆ğ: Üreme Çağı ve Postmenopozal Dönem \\ Kadınlar
}

Derya KAYA ŞENOL ${ }^{1}$, Filiz POLAT ${ }^{1}$, Merve DOĞAN ${ }^{2}$

\begin{abstract}
Objective: An important factor in the protection of women from gynecological cancers is awareness. Increasing awareness of gynecological cancer is important in terms of early diagnosis of the disease, treatment and reduction of mortality. The research was conducted to determine the gynecological cancer awareness of women of reproductive age and postmenopausal period. Methods: The study, designed as a descriptive cross-sectional type, was conducted with women who were admitted to a state hospital in Cankırı between October 2019 and February 2020. The sample consisted of 339 women who met the inclusion criteria. At the data collection stage, the 'Participant Information Form' and 'Gynecological Cancers Awareness Scale', which includes sociodemographic obstetric and general health characteristics (age, marital status, education, number of pregnancy, genital cancer history, sexual disease history) " used. SPSS 21.0 (Statistical packet for Social Sciences for Windows) package program was used for the analysis of the data obtained from the study. Results: In the study, it was determined that women in the age group of 36-50, working, with 1-3 pregnancies and children, using oral contraceptives and having ideas about whether gynecological cancers can be prevented, had higher Gynecological Cancers Awareness Scale mean scores. It was determined that the gynecological Cancer Awareness Scale total mean scores were higher in women of reproductive age (150.7 \pm 20.6$)$ compared to women in the postmenopausal period $(144.4 \pm 18.5)$, and the difference between them was statistically significant $(\mathrm{p}<0.05)$. Conclusion: According to the research results; In women, factors such as education, number of pregnancies, number of births, family planning used and being in reproductive age affect gynecological cancer awareness. Postmenopausal women need information about gynecological cancer awareness.
\end{abstract}

Key words: Gynecological cancer, awareness, woman

\section{ÖZET}

Giriș: Kadınların jinekolojik kanserlerden korunmasında önemli bir faktör farkındalıktır. Jinekolojik kanser farkındalığının artması hastalığın erken tanılanması, tedavisi ve mortalitenin azaltılması açısından önemlidir. Araştırma üreme çağındaki ve postmenopozal dönemdeki kadınların jinekolojik kanser farkındalıklarını belirlemek amacıyla yapılmıștır. Yöntem: Tanımlayıcı kesitsel tipte tasarlanan çalıșma, Ekim 2019 - Şubat 2020 tarihleri arasında Cankırı ilinde bir devlet hastanesine başvuran kadınlar ile yürütülmüştür. Araştırmaya dahil edilme kriterlerine uyan 339 kadın örneklemi oluşturmuş̧ur. Veri toplama aşamasında kadınların sosyo-demografik obstetrik ve genel sağlık özelliklerini (yaş, medeni durum, eğitim, gebelik sayısı, genital kanser öyküsü, cinsel hastalık öyküsü gibi toplam 20 soru) içeren 'Katılımcı Bilgi Formu" ve "Jinekolojik Kanserler Farkındalık Ölçeği" kullanılmıştır. Araştırmadan elde edilen verilerin analizi için SPSS 21.0 (Statistical packet for Social Sciences for Windows) paket programı kullanılmıştır. Bulgular: Araştırmada 36-50 yaş grubunda olan, çalışan, 1-3 arası gebelik ve çocuk sayısı olan, oral kontraseptif kullanan ve jinekolojik kanserlerin önlenip önlenemeyeceği konusundaki fikirleri olan kadınların Jinekolojik Kanserler Farkındalık Ölçeği puan ortalamalarının daha yüksek olduğu belirlenmiștir. Jinekolojik Kanser Farkındalık

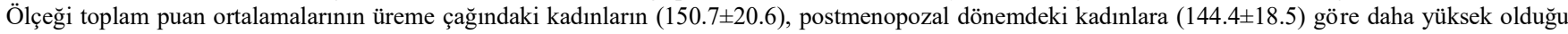
ve aralarındaki farkın istatistiksel olarak anlamlı olduğu $(\mathrm{p}<0.05)$ belirlenmiștir. Sonuç: Araștırma sonuçlarına göre; kadınlarda eğitim, gebelik sayısı, doğum sayısı, kullanılan aile planlaması ve üreme çağında olma gibi faktörler jinekolojik kanser farkındalıklarını etkilemektedir. Postmenopozal dönemdeki kadınların jinekolojik kanser farkındalı̆̆

Anahtar Kelimeler: Jinekolojik kanser, farkındalık, kadın

Received / Geliş tarihi: 05.10.2020, Accepted / Kabul tarihi: 05.12.2020

${ }^{1}$ Osmaniye Korkut Ata Üniversitesi, Sağl1k Bilimleri Fakültesi, Ebelik Bölümü, Osmaniye

${ }^{2}$ Çankırı Karatekin Üniversitesi, Sağlık Bilimleri Fakültesi, Hemşirelik Bölümü, Çankırı

*Address for Correspondence / Yazışma Adresi: Filiz POLAT, Osmaniye Korkut Ata Üniversitesi, Karacaoğlan Yerleşkesi D-Blok Sağlık Bilimleri Fakültesi, Ebelik Bölümü, Merkez - Osmaniye - TÜRKIYY, E-mail: filizmermer@yahoo.com

Cevik A, Alan S. The Relationship Between Oxytocin Level and Postpartum Depression. TJFMPC, 2021;15(1): 56-62.

DOI: $10.21763 /$ tjfmpc. 805231 


\section{Gİiş̧}

Kadınlar menarştan menopoza kadar olan yaşam sürecinde ve yaşlılık döneminde üreme sistemi ile ilgili olarak gelişebilecek rahatsızlıklar açısından risk altındadırlar. ${ }^{1}$ Jinekolojik kanserler kadınlarda meme kanserinden sonra morbidite ve mortalite bakımından oldukça önemli bir yer tutmaktadır., ${ }^{3}$ Jinekolojik kanserlerin, tüm kadın kanserlerinin yaklaşı olarak 1/5'ini oluşturduğu tahmin edilmektedir ${ }^{1}$.

Globocan 2018 yılı verilerine göre dünya çapında kadınlarda en fazla görülen kanser türünün jinekolojik kanserler olduğ ${ }^{2}$, kadınlarda en fazla görülen kanser çeşidi sıralamasında da jinekolojik kanserlerden biri olan serviks kanserinin dördüncü sırada yer aldığı belirtilmiştir. ${ }^{1,4}$ Dünyada serviks kanseri vakalarının, yaklaşık \% 86'sı gelişmekte olan ülkelerde olup, bu kanser türü jinekolojik kanserler arasında önde gelen hastalık ve ölüm nedenlerinden biridir. ${ }^{5}$ Türk Kanser Araştırması sonuçlarına göre ise; Türkiye'de kadınlar arasında önde gelen ölüm nedenleri over, endometriyal ve serviks kanserleridir. ${ }^{6}$

Jinekolojik kanserler farklı belirti ve semptomlar göstermiş olsa bile araştırmalar yaş, sigara içme, HIV enfeksiyonu, obezite, insan papilloma virüsü enfeksiyonu, belirli kimyasallara maruz kalma gibi risk faktörlerinin ortak olduğunu göstermiştir. ${ }^{7} \mathrm{Bu}$ kanserler, fizyolojik belirtilerinin yanı sıra ailelerinin günlük yaşamını, kadının kişilerarası ilişkilerini, iş yaşamını ve yaşam kalitesini etkileyen, strese neden olan hastalıklardır. Ayrıca kadının, doğurganlık, cinsel yaşamı ve üreme sisteminin yapısını ilgilendiren önemli bir konudur. $3,8,9$

Kanserler, günümüzde ve gelecekte en önemli sağlık sorunlarından ve mortalite nedenlerinden biri olmaya devam edeceği için ${ }^{10}$ ölüm oranlarının azaltılmasında, korunma ile beraber erken dönemde tanılanması önemlidir. ${ }^{11}$ Özellikle hastalığın erken evresinde tanılandığında jinekolojik kanserlerden iyileşenlerin sayısı, son yıllarda önemli ölçüde artmıştır. Ancak kadınların sağlık sorunlarını önemsememe, bilgi eksikliği, utanma, ekonomik sorunlar gibi sebeplerle sağlık kuruluşlarına başvurmadıkları ya da erteledikleri bilinmektedir. ${ }^{12}$

Kadınların jinekolojik kanserlerden korunmasında önemli olan diğer bir faktör ise farkındalıktır. Jinekolojik kanserler farkındalığı; bireyleri kanser risklerini nasıl azaltacakları konusunda eğitmek, teşhis ve tedavi konusunda erken adım atmalarını sağlamak anlamına gelmektedir ${ }^{11}$. Jinekolojik kanser farkındalığının artması, hastalığın erken tanılanması, tedavisi ve mortalitenin azaltılması açısından olumlu bir etki sağlayacaktır. ${ }^{1,11}$ Bundan dolayı bu araştırma üreme çağındaki ve postmenopozal dönemdeki kadınların jinekolojik kanser farkındalıklarını belirlemek amacıyla yapılmıştır.

\section{YÖNTEM}

Tanımlayıcı kesitsel tipteki bu araştırma Ekim 2019-Şubat 2020 tarihleri arasında Çankırı ilinde bir devlet hastanesine başvuran kadınlar ile yürütülmüştür. Araştırmanın evrenini, Çankırı Devlet Hastanesine herhangi bir nedenle başvuran üreme çağındaki ve postmenopozal dönemdeki kadınlar oluşturmuştur. Araştırmanın örneklemini, Ekim 2019-Şubat 2020 tarihleri arasında hastaneye gelen, araştırmaya dâhil edilme kriterlerine uyan 339 kadın oluşturmuştur. Üreme çağında $(n=243)$ ve postmenopozal dönemde $(\mathrm{n}=96)$ olan, jinekolojik kanser tanısı almayan, iletişim problemi olmayan ve araştırmaya katılmaya gönüllü olan kadınlar çalışmaya dâhil edilmiştir.

\section{Veri Toplama Yöntemi ve Formu}

Veri toplama formu iki bölümden oluşmaktadır. İlk bölümde kadınların sosyo-demografik, obstetrik ve genel sağlık özellikleri (yaş, medeni durum, eğitim, gebelik sayısı, genital kanser öyküsü, cinsel hastalık öyküsü gibi toplam 20 soru) ile ilgili sorulardan oluşan 'Katılımcı Bilgi Formu', ikinci bölümde ise "Jinekolojik Kanserler Farkındalık Ölçeği', kullanılmıştır. Veriler araştırmacı tarafından yüz yüze görüşme tekniği kullanılarak toplanmıştır. Anket formunun uygulanması ortalama 10 dakika sürmüştür.

Jinekolojik Kanserler Farkındalık Ölçeği (JIKKFÖ): Kadınların jinekolojik kanserlerle ilgili farkındalıklarını belirlemek amacıyla 2017 yılında Dal ve Ertem tarafından geliştirilmiş bir ölçektir. JíKFÖ 20-65 yaş arasındaki evli kadınlar için geliştirilen 41 madde ve dört alt boyuttan oluşan 5'li likert tipi bir ölçektir. Ölçekte yer alan maddeler (1) Kesinlikle katılmiyorum, (2) Katılmiyorum, (3) Kararsızım (4) Katılıyorum, (5) Kesinlikle katılıyorum şeklindeki ifadeler ile değerlendirilmektedir. JIKKFÖ'nin 20-41. maddeleri "Jinekolojik Kanserlerde Rutin Kontrol ve Ciddi Hastalık Algısı Farkındalığı” alt boyutunu, 3-11. maddeleri "Jinekolojik Kanser Riskleri Farkındalığı" alt boyutunu, 14-19 maddeleri "Jinekolojik Kanserlerden Korunma Farkındalığı" alt boyutunu, 1-2, 12-13. maddeleri "Jinekolojik Kanserlerde Erken Tanı ve Bilgi Farkındalığı” alt boyutunu oluşturmaktadır. Ölçekten alınacak en düşük puan 41 , en yüksek puan 205 'dir. Kadınların JíKFÖ'nden alacakları puan arttıkça jinekolojik kanser farkındalıkları da artmaktadır. JİKFÖ'nin Cronbach Alpha değeri 0.944'tür. ${ }^{12}$ Bizim çalışmamızda Cronbach Alpha değeri ise 0.930'dur. 


\section{Verilerin Değerlendirilmesi}

Araştırmadan elde edilen bulguların analizi için SPSS 21.0 (Statistical Packet for Social Sciences for Windows) paket programı kullanılmıştır. Araştırma verilerinin değerlendirilmesinde tanımlayıcı istatistiksel yöntemlerinden yüzde, frekans, ortalama, standart sapma, minimummaksimum değerler ve normal dağılımın incelenmesi için Skewness ve Kurtosis $( \pm 1)$ dağılım testi kullanılmıştır. İstatistiksel hesaplamaları için $\mathrm{t}$ testi, Anova testleri kullanılmıştır. İstatistiksel anlamlılık için $\mathrm{p}<0.05$ değeri kabul edilmiştir.

\section{Araştırmada Etik}

Araştırmanın yapılabilmesi için araştırma verilerinin toplanacağı kurumdan ve bir üniversitenin bilimsel araştırmalar etik kurulundan (Karar no: 2019/132) onay alınmıștır. Kadınlara araştırmanın amacı açıklanarak hem sözel hem de yazılı onamları alınmıştır. Bu çalışma, Helsinki Deklarasyonu Prensipleri'ne uygun bir biçimde yapılmıştır.

\section{BULGULAR}

Tablo 1'de araştırmaya alınan kadınların yaş ortalamasının $39.25 \pm 14.5$, gebelik sayı1 ortalamasının $2.91 \pm 2.8$, doğum sayısı ortalamasının $2.37 \pm 2.2$, yaşayan çocuk sayısı ortalamasının $2.18 \pm 1.9$, ilk gebelik yaş ortalamasının $20.7 \pm 3.6$, ilk adet yaş ortalamasının $13.2 \pm 1.2$, menopoz yaş ortalamasının $47.4 \pm 4.1$ olduğu belirlenmiştir.

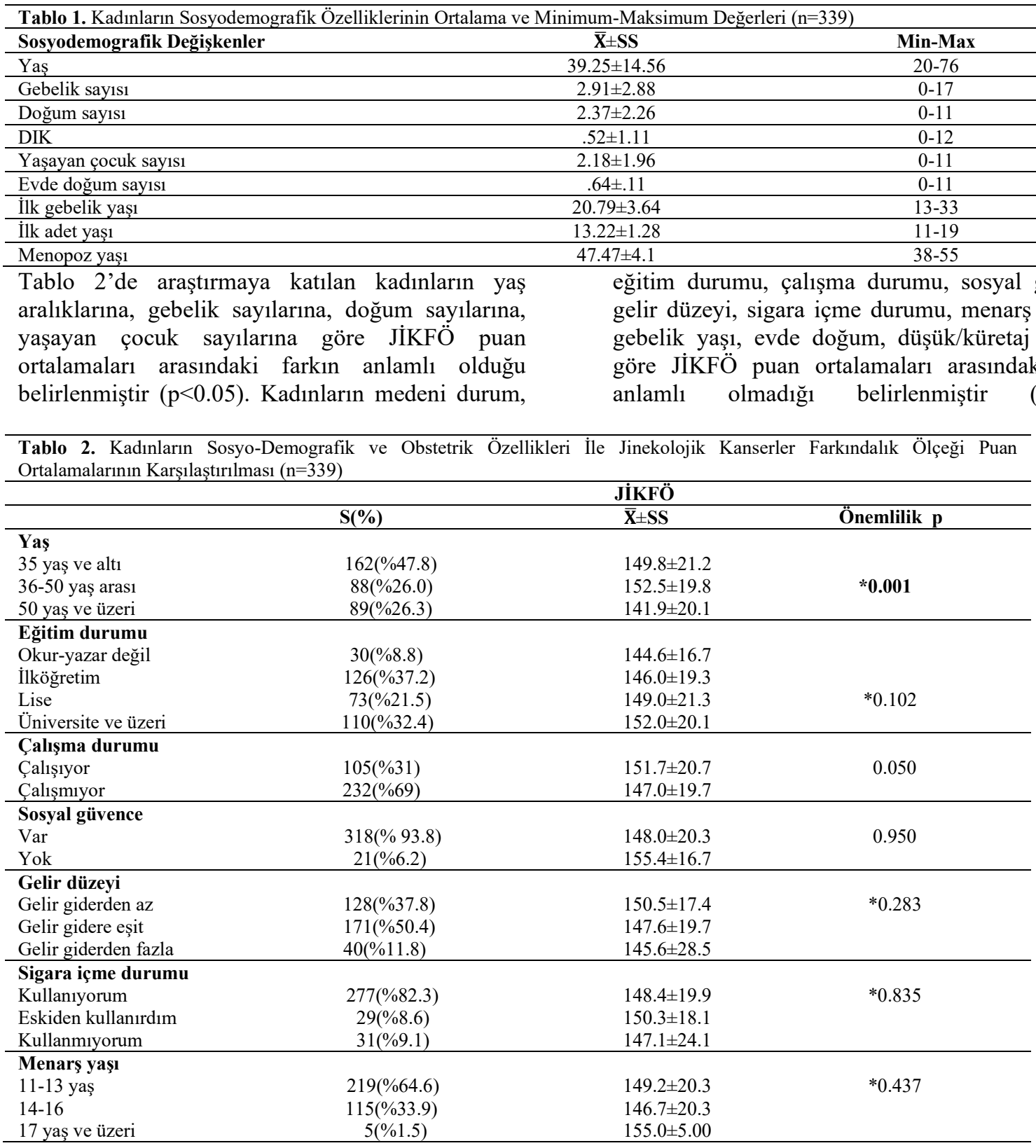




\begin{tabular}{|c|c|c|c|}
\hline \multicolumn{4}{|l|}{ İlk gebelik yașı } \\
\hline 19 yaş ve altı & $103(\% 30.4)$ & $147.9 \pm 17.8$ & $* 0.440$ \\
\hline 20 yaş ve üzeri & $144(\% 42.5)$ & $150.0 \pm 18.9$ & \\
\hline Gebelik yok & $92(\% 27.1)$ & $146.7 \pm 24.1$ & \\
\hline \multicolumn{4}{|l|}{ Gebelik Sayısı } \\
\hline Hiç yok & $92(\% 27.1)$ & $146.7 \pm 24.1$ & $* 0.000$ \\
\hline $1-3$ aras1 & $128(\% 37.8)$ & $153.9 \pm 16.6$ & \\
\hline 4 ve üzeri & $119(\% 35.1)$ & $144.0 \pm 19.1$ & \\
\hline \multicolumn{4}{|l|}{ Doğum Sayısı } \\
\hline Doğum yapmayan & $93(\% 27.4)$ & $146.8 \pm 24.0$ & $*_{0.001}$ \\
\hline $1-3$ arasi & $163(\% 48.1)$ & $152.4 \pm 16.9$ & \\
\hline 4 ve üzeri & $83(\% 24.5)$ & $142.5 \pm 19.8$ & \\
\hline \multicolumn{4}{|l|}{ Yaşayan Çocuk } \\
\hline Yok & $93(\% 27.4)$ & $146.8 \pm 24.0$ & $* 0.007$ \\
\hline 1-3 çocuk & $176(\% 51.9)$ & $151.5 \pm 16.9$ & \\
\hline 4 ve üzeri & $70(\% 20.6)$ & $143.0 \pm 20.8$ & \\
\hline \multicolumn{4}{|l|}{ Evde doğum } \\
\hline Var & $53(\% 15.6)$ & $144.3 \pm 19.8$ & 0.103 \\
\hline Yok & $286(\% 84.4)$ & $149.2 \pm 20.1$ & \\
\hline \multicolumn{4}{|l|}{ Düșük/Küretaj } \\
\hline Var & $100(\% 29.5)$ & $148.2 \pm 16.3$ & 0.897 \\
\hline Yok & $239(\% 70.5)$ & $148.5 \pm 21.6$ & \\
\hline
\end{tabular}

Tablo 3'de araştırmaya katılan kadınların kullandıkları aile planlaması yöntemlerine ve genital kanserlerin önlenip önlenemeyeceği konusundaki fikirlerine göre Jinekolojik Kanserler Farkındalık Ölçeği puan ortalamaları arasındaki farkın anlamlı olduğu belirlenmiştir $(p<0.05)$.
Kadınların sağlığını algılama, kronik hastalık, ailede genital kanser, cinsel hastalık öyküsüne göre Jinekolojik Kanserler Farkındalık Ölçeği puan ortalamaları arasındaki farkın anlamlı olmadığ belirlenmiştir

Tablo 3. Kadınların Genel Sağlık Özellikleri İle Jinekolojik Kanserler Farkındalık Ölçeği Puan Ortalamalarının Karşılaştırılması

\begin{tabular}{|c|c|c|c|}
\hline & & JíKFÖ & \\
\hline & $\mathbf{S}(\%)$ & $\overline{\mathbf{X}} \pm \mathbf{S S}$ & Önemlilik p \\
\hline \multicolumn{4}{|l|}{ Aile planlaması yöntemi } \\
\hline Kullanmiyor & $216(\% 63.7)$ & $148.0 \pm 17.7$ & $* 0.042$ \\
\hline Ria & $15(\% 4.4)$ & $156.1 \pm 13.6$ & \\
\hline Kondom & $19(\% 5.6)$ & $136.4 \pm 36.1$ & \\
\hline OKS & $8(\% 2.4)$ & $160.3 \pm 18.0$ & \\
\hline Enjeksiyon & $5(\% 1.5)$ & $152.6 \pm 8.11$ & \\
\hline Geri çekme & $70(\% 20.6)$ & $150,2 \pm 22.7$ & \\
\hline Tüp ligasyon & $6(\% 1.8)$ & $143.0 \pm 2.36$ & \\
\hline \multicolumn{4}{|l|}{ Sağlığını algılama } \\
\hline Çok iyi & $41(\% 12.1)$ & $143.0 \pm 24.0$ & $* 0.323$ \\
\hline İyi & $135(\% 39.8)$ & $149.4 \pm 16.8$ & \\
\hline Orta/fena değil & $138(\% 40.7)$ & $148.8 \pm 21.4$ & \\
\hline Kötü & $19(\% 5.6)$ & $152.7 \pm 24.4$ & \\
\hline Çok kötü & $6(\% 1.8)$ & $142.8 \pm 24.4$ & \\
\hline \multicolumn{4}{|l|}{ Kronik Hastalık } \\
\hline Var & $96(\% 28.3)$ & $148.9 \pm 17.7$ & 0.815 \\
\hline Yok & $24(\% 71.7)$ & $148.3 \pm 21.1$ & \\
\hline \multicolumn{4}{|l|}{ Ailede genital kanser } \\
\hline Var & $46(\% 13.6)$ & $146.0 \pm 14.4$ & 0.389 \\
\hline Yok & $293(\% 86.4)$ & $148.8 \pm 20.9$ & \\
\hline \multicolumn{4}{|l|}{ Ailede kim genital kanser } \\
\hline Aile genital kanser yok & $287(\% 84,7)$ & $148.9 \pm 20.8$ & \\
\hline Anne/anneanne/babaanne & $22(\% 6,5)$ & $143.0 \pm 17.8$ & $* 0.807$ \\
\hline Kızkardeş & $10(\% 2,9)$ & $145.3 \pm 8.96$ & \\
\hline Kendisi & $7(\% 2,1)$ & $152.6 \pm 20.6$ & \\
\hline Hala/Teyze & $8(\% 2,4)$ & $149.1 \pm 10.8$ & \\
\hline Kız1 & $5(\% 1,5)$ & $147.2 \pm 19.6$ & \\
\hline \multicolumn{4}{|l|}{ Cinsel hastalık öyküsü } \\
\hline Bende oldu & $17(\% 5)$ & $149.5 \pm 22.8$ & \\
\hline Eşimde oldu & $15(\% 4,4)$ & $153.9 \pm 20.3$ & *0.746 \\
\hline Her ikimizde de olmadı & $294(\% 86,4)$ & $148.1 \pm 20.3$ & \\
\hline Her ikimizde de oldu & $13(\% 3,8)$ & $149.1 \pm 11.8$ & \\
\hline \multicolumn{4}{|c|}{ Genital kanserler önlenebilir mi } \\
\hline Evet & $211(\% 62,2)$ & $152.4 \pm 17.6$ & $* 0.000$ \\
\hline Hayır & $20(\% 5,9)$ & $134.1 \pm 36.9$ & \\
\hline Bilmiyorum & $108(\% 31,9)$ & $143.4 \pm 18.4$ & \\
\hline
\end{tabular}

JíKFÖ= Jinekolojik Kanserler Farkındalık Ölçeği $\mathbf{t}=$ Bağımsız gruplarda t testi. *F= ANOVA test $\mathbf{O K S}=$ Kombine Oral Kontraseptif 
Tablo 4'te Jinekolojik Kanser Farkındalık Ölçeği'nin '’Jinekolojik Kanserlerde Rutin Kontrol ve Ciddi Hastalık Algısı Farkındalığı Alt Boyutu', puan ortalamalarının üreme çağındaki kadınlarda $82.1 \pm 13.3$, postmenopozal dönemdeki kadınlarda $79.7 \pm 9.5$ olduğu ve puan ortalamaları arasındaki farkın anlamlı olmadığı ( $>0.05)$, 'Jinekolojik Kanser Riskleri Farkındalığı Alt Boyutu', puan ortalamalarının üreme çağındaki kadınlarda $29.1 \pm 5.8$, postmenopozal dönemdeki kadınlarda $27.8 \pm 6.08$ olduğu ve puan ortalamaları arasındaki farkın anlamlı olmadığı ( $>0.05)$, 'Jinekolojik
Kanserlerden Korunma Farkındalığı Alt Boyutu', puan ortalamalarının üreme çağındaki kadınlarda $22.6 \pm 4.06$, postmenopozal dönemdeki kadınlarda $21.2 \pm 4.8$ olduğu ve puan ortalamaları arasındaki farkın anlamlı olduğu $(\mathrm{p}<0.05)$, 'Jinekolojik Kanserlerde Erken Tanı ve Bilgi Farkındalığı Alt Boyutu' puan ortalamalarının üreme çağındaki kadınlarda $16.7 \pm 3.04$, postmenopozal dönemdeki kadınlarda $16.2 \pm 3.5$ olduğu ve puan ortalamaları arasındaki farkın anlamlı olmadı $\breve{g}_{1} \quad(\mathrm{p}>0.05)$ belirlenmiştir.

\begin{tabular}{|c|c|c|c|}
\hline $\begin{array}{l}\text { Jinekolojik Kanser Farkındalık Ölçek Alt } \\
\text { Boyutları (JíKFÖ) }\end{array}$ & $\begin{array}{c}\text { Üreme çağındaki } \\
\text { kadınlar } \\
\text { n=243(\%71.7) }\end{array}$ & $\begin{array}{c}\text { Postmenopozal } \\
\text { kadınlar } \\
\text { n=96(\%28.3) }\end{array}$ & Önemlilik \\
\hline & $\overline{\mathbf{X}} \pm \mathbf{S S}$ & $\overline{\mathbf{X}} \pm \mathbf{S S}$ & $\mathbf{p}$ \\
\hline $\begin{array}{l}\text { Jinekolojik Kanserlerde Rutin Kontrol ve Ciddi } \\
\text { Hastalık Algısı Farkındalığı }\end{array}$ & $82.13 \pm 13.3$ & $79.7 \pm 9.59$ & 0.106 \\
\hline Jinekolojik Kanser Riskleri Farkındalığı & $29.10 \pm 5.89$ & $27.8 \pm 6.08$ & 0.071 \\
\hline Jinekolojik Kanserlerden Korunma Farkındalığı & $22.62 \pm 4.06$ & $21.29 \pm 4.85$ & 0.011 \\
\hline $\begin{array}{l}\text { Jinekolojik Kanserlerde Erken Tanı ve Bilgi } \\
\text { Farkındalığı }\end{array}$ & $16.74 \pm 3.04$ & $16.21 \pm 3.58$ & 0.172 \\
\hline JÍKFÖ Toplam Puan & $150.7 \pm 20.6$ & $144.4 \pm 18.5$ & 0.022 \\
\hline
\end{tabular}

Araştırmada 'Jinekolojik Kanser Farkındalık Ölçeği", toplam puan ortalamalarının üreme çağındaki kadınlarda $150.7 \pm 20.6$, postmenopozal dönemdeki kadınlarda144.4 \pm 18.5 olduğu ve toplam puan ortalamaları arasındaki farkın anlamlı olduğu $(\mathrm{p}<0.05)$ belirlenmiştir (Tablo 4).

\section{TARTIŞMA}

Çalışmada kadınların yaş ortalamaları $39.25 \pm 14.56$ idi. Obstetrik özelliklerine bakıldığında gebelik sayıs1 ortalamasının 2.91 \pm 2.88 , doğum sayıs1 ortalamasının $2.37 \pm 2.26$, yaşayan çocuk sayısı ortalamasının 2.18 1.96 , ilk gebelik yaş ortalamasının $20.79 \pm 3.64$ olduğu belirlenmiştir. TNSA 2018 (Türkiye Nüfus ve Sağlık Araştırması) verilerine göre ülkemizde ortanca ilk doğum yaş1 23.3, ortalama doğum sayısı 2.8, halen evli kadınlarda canlı doğum sayı 2.37 ve yaşayan çocuk sayı 2.29 olarak saptanmıştır. Çalışmada kadınların menopoz yaş ortalamasının $47.47 \pm 4.1$ olduğu görüldü. TNSA 2018 verilerine göre ise ülkemizde 48-49 yaş aralığındaki kadınların \%45.1'inin menopozal dönemde olduğu bildirilmektedir. ${ }^{13}$ Sonuçlarımız ülke verileri ile benzerlik göstermektedir.

TNSA 2018 verileri incelendiğinde kadınların yaş aralıkları ile gebelik ve doğum sayıları arasında pozitif bir ilişki olduğu görülmektedir. İlk evlenme yaş1 40 yaş üzerinde 20.8 iken, 34 yaş altında 21.6 ve daha üzeridir. İlk doğum yaşı 35 yaş altı kadınlarda 23.6 ve daha üzeri iken 35 yaş üzeri kadınlarda 22.5 ve altındadır. ${ }^{13}$ Veriler 2018 yılı itibariyle 40 yaș ve üzeri kadınlarda evlenme ve ilk gebelik yaşının daha erken olduğunu göstermektedir. Türk toplumunda kadınların aktif cinsel hayata genellikle evlilikle birlikte başlamaları, obstetrik ya da jinekolojik nedenlerle muayeneye gitmeleri, üreme sağlığı hizmetini daha fazla almaları 36-50 yaş aralığında olan kadınlarda jinekolojik kanser farkındalığının daha yüksek olması sonucunu açıklayabilir. Yapılan benzer bir çalışmada da yaş grupları ile jinekolojik kanser farkındalık ölçeği toplam ortanca değeri arasında istatistiksel olarak anlamlı farklılık saptandı̆̆ 1 belirtilmektedir. ${ }^{2}$

Araştırmada aile planlaması yöntemi olarak rahim içi araç ve oral kontraseptif kullanan kadınların Jinekolojik Kanserler Farkındalık Ölçeği puan ortalamaları anlamlı düzeyde yüksekti. TNSA 2018 verileri de halen evli kadınların yaş dağılımlarına göre gebeliği önleyici yöntem kullanımları incelendiğinde Ria'nin en fazla 35-39 yaş aralığındaki kadınlarda (17.1), oral kontraseptiflerin ise 30-39 yaş aralığında yüksek olduğunu görmekteyiz. ${ }^{13}$ Daha sık izlem ve sağlık kuruluşuna başvuru gerektiren bu durumlar, sağlık personelinden alınan danışmanlık hizmetinin kanser farkındalığına olumlu etkisini göstermektedir.

Araştırmada jinekolojik kanserlerin önlenebileceğini düşünen kadınların JIKKFÖ puan ortalamaları anlamlı düzeyde yüksekti. Literatüre bakıldığında benzer çalışmalarda kadınların büyük çoğunluğunun (\%88.8) jinekolojik kanserlerin 
erken teşhis ve tedavisinin mümkün olduğunu ifade ettikleri bildirilmiştir. ${ }^{14}$

Çalışmada üreme çağındaki kadınların ' Jinekolojik Kanser Farkındalık Ölçeği', toplam puan ortalamalarının $\quad 150.7 \pm 20.6$, postmenopozal dönemdeki kadınların $144.4 \pm 18.5$ olduğu saptandı. Çalışma sonucu postmenopozal dönemdeki kadınlarda jinekolojik kanser farkındalığının daha az olduğunu göstermektedir. Yapılan diğer çalışmalara bakıldığında Jinekolojik Kanser Farkındalık Ölçeği puan ortalamalarının Gözüyeşil ve arkadaşlarının (2019) çalışmasında 153, Alp Dal ve arkadaşlarının (2019) çalışmasında akademik personelde 157.05 , idari personelde 150.94 , sağlık personelinde 159.96 olarak bildirilmiştir. ${ }^{2,11}$ Şahin ve Sayın'ın (2015) çalışmalarında; kadınların endometrium, over ve serviks kanseri farkındalıklarının yüksek olduğu ifade edilmiştir. ${ }^{15}$ Bununla birlikte yapılan çalışmalarda da kadınların jinekolojik kanserlerle ilgili bilgi düzeylerinin düşük olduğu belirtilmektedir. ${ }^{16,}{ }^{17}$ Amerika'da (2013) 132 kadınla yapılan bir araştırmada; kadınların jinekolojik kanserlerin belirtilerini bilmedikleri tespit edilmiştir. ${ }^{18}$ Ülkemizde yapılan araştırmaların genellikle serviks kanseriyle ilgili olduğu, jinekolojik kanserlerde farkındalık ile ilgili çalışmaların sınırlı sayıda olduğu belirlenmiştir. Türkiye'de Bekar ve arkadaşlarının (2011) yaptıkları araştırmada kadınların \%88.8'inin jinekolojik kanserler için erken teşhis ve tedavinin mümkün olduğunu bildikleri saptanmıştır. ${ }^{19}$ Başka bir çalışma ise; 15-64 yaş aralığında olan 384 sağlık çalışanı ve poliklinik hastasıyla yapılmış olup; PAP-Smear yaptıran sağlık çalışanı ve poliklinik hastasının jinekolojik kanser farkındalığının yüksek olduğu görülmüştür. ${ }^{15}$

Jinekolojik kanser oluşumunda yaş, ekonomik durum, bireyin çalıştığı meslek, ailede kanserli bireylerin varlığı, çevresel etmenler, sigara veya alkol gibi sağlığa zararlı alışkanlıklar, hareketsiz yaşam, perinatal gelişim, virüsler gibi faktörler risk oluşturmaktadır. ${ }^{20}$

Jinekolojik kanserlerin sıklıkla görüldüğü yaşlar incelendiğinde; korpus uteri ve over kanserinin 65 yaş ve sonrasında arttığ1, 70 yaş üzerinde kadınlarda ilk 10 kanser türü sıralaması içerisinde en fazla görülen jinekolojik kanser tipinin korpus uteri kanseri olduğu, ikinci sırada ise over kanseri görüldüğü bildirilmektedir. ${ }^{21}$ Jinekolojik kanserler içinde daha düşük insidansta seyreden vulva kanseri görülme riskinin yaşla birlikte arttığı da belirtilmektedir. $^{22,23,}{ }^{24}$ Literatüre baktığımızda ise menopozal dönem sonrası kanser farkındalığına yönelik yapılan çalışmaların az olduğ $\mathrm{u}^{24}$ ve bu grubun koruyucu sağlık hizmetlerinden yeteri kadar yararlanmadığı görülmektedir. ${ }^{25}$ Çalışma sonuçları özellikle menopozal dönem sonrası olmak üzere her yaş grubu kadınlarda farkındalığın araştırılmasının ve artırılmasının gerekliliğini ortaya koymaktadır.

\section{SONUÇ}

Araştırma sonuçlarına göre; kadınlarda eğitim, gebelik sayısı, doğum sayısı, kullanılan aile planlaması ve üreme çağında olma gibi faktörler jinekolojik kanser farkındalıklarını etkilemektedir. Özellikle postmenopozal dönemdeki kadınların üreme çağında olan kadınlara göre jinekolojik kanser farkındalığı konusunda daha fazla bilgi gereksinimleri bulunmaktadır.

Kadın sağlığını geliştirmek ve jinekolojik kanser farkındalığını artırmak için sağlık personelinin tüm yaş gruplarındaki kadınlara geniş kapsamlı eğitim programları planlamaları ve eğitimlerin sürekliliği büyük önem taşımaktadır. Özellikle riskli grupta olan ve koruyucu sağlık hizmetlerinde göz ardı edilen postmenopozal dönemde olan kadınların jinekolojik kanserlere karşı farkındalığının arttırılması gerekmektedir. Koruyucu sağlık hizmetlerinin sunulduğu sağlik kuruluşlarında jinekolojik kanser farkındalığını artırmaya yönelik, bireylerin sosyo-demografik ve jinekolojikobstetrik özellikleri de göz önünde bulundurularak eğitimlerin planlanması ve yürütülmesi önerilmektedir.

\section{Teșekkür}

Araştırmaya katılan tüm bireylere teşekkür ederiz.

\section{KAYNAKLAR}

1. Eker A, Aslan E. Jinekolojik kanser hastalarında psiko-sosyal yaklaşım. HEAD 2017;14 (4): 298-303.

2. Ebru G, Ayten AD, Filiz T. Evaluation of gynecological cancer awareness of women's applying for a family health center. TJFMPC 2020; $14 \quad$ (2): $177-185 . \quad$ DOI: 10.21763/tjfmpc.730022

3. Pinar G, Pinar T, Akalin A, Saydam T, Ayhan A. Problematic areas related to sexual life of individuals with gynecological cancer: a qualitative study in Turkey. International Journal of Hematology and Oncology 2015; 25: $195-204$

4. Ersin F, Kissal A, Polat P, Koca BD, Erdoğan M. Kadın sağlık personelinin servikal kansere yönelik algıları ve bunu etkileyen faktörler. Hemşirelikte Araştırma Geliştirme Dergisi 2016; 18(2-3): 31-43.

5. Mutambara J, Mutandwa P, Mahapa M, Chirasha V, Nkiwane S, Shangahaidonhi T. Knowledge, attitudes and practices of cervical cancer screening among women who attend traditional churches in Zimbabwe. Journal of 
Cancer Research and Practice 2017; 4(2): 5358.

6. Akalin A, Pinar G. Unmet needs of women diagnosed with gynecologic cancer: An overview of literature. J Palliat Care Med 2016; 6: 249. doi:10.4172/2165-7386.1000249.

7. Campo L, Zhang C, Breuer EK. EMT-Inducing molecular factors in gynecological cancers. Biomed Res Int 2015; 420891. doi:10.1155/2015/420891.

8. Türkiye Cumhuriyeti Sağlık Bakanlığı, Türkiye Halk Sağlığı Kurumu (2016). Kanser İstatistikleri. Kanser Bölümü. https://hsgm.saglik.gov.tr/tr/kanseristatistikleri. Erişim Tarihi: 25.09.2020

9. McCallum M, Jolicoeur L, Lefebvre M, Babchishin LK, Robert-Chauret S, Le T, et al. Supportive care needs aier gynecologic cancer: where does sexual health fit in? Oncol Nurs Forum 2014; 41: 297-306.

10. Gözüyeşil E, Arıöz DA, Ünal AKS. Kadınların serviks kanserinden korunma ve erken taniya yönelik tutumlarının değerlendirilmesi. STED 2019; 28(4): 228-237.

11. Alp DN, Akkuzu G, Çetinkaya ŞY. Ufuk Üniversitesi kadın çalışanlarının jinekolojik kanser farkındalığının incelenmesi. Ebelik ve Sağlık Bilimleri Dergisi 2020; 3(2): 91-99.

12. Dal NA, Ertem G. Jinekolojik kanserler farkındalık ölçeği geliştirme çalışması. İnsan ve Toplum Bilimleri Araştırmaları Dergisi 2017;6(5): 2351-2367.

13. 2018 Türkiye Nüfus ve Sağlı Araştırması (2018 TNSA) Hacettepe Üniversitesi Nüfus Etütleri. 54-56. http://www.hips.hacettepe.edu.tr/tnsa2018/rapo r/TNSA2018_ana_Rapor.pdf. Erişim Tarihi: 25:09.2020

14. Bekar M, Guler H, Evcili F, Demirel G, Duran Ö. Determining the knowledge of women and their attitudes regarding gynecological cancer prevention. Asian Pacific Journal of Cancer Prevention 2013; 14(10): 6055-6059

15. Şahin D, Sayın NC. Knowledge, attitude and behavior about gynecologic cancers in women admitted to and healthcare staff working at the state hospital in Kirklarelı. Indian Journal Of Applied Research 2015; 5(3): 294-297.
16. Moore AR, Driver N. Knowledge of cervical cancer risk factors among educated women in lome, Togo: Half-Truths and misconceptions. SAGE Open 2014; 4(4): 1-8.

17. Shankar A, Rath GK, Roy S, Malik A, Bhandari R, Kishor K, et al., Level of awareness of cervical and breast cancer risk factors and safe practices among college teachers of different states in india: do awareness programmes have an impact on adoption of safe practices. Asian Pac J Cancer Prev 2015;16(3): 927-32.

18. Cooper CP, Polonec L, Stewart SL, Gelb CA. Gynaecologic cancer symptom awareness, concern and care seeking among us women: A Multi-site qualitative study. Family Practice 2013; 30(1): 96-104.

19. Bekar M, Guler H, Evcili F, Demirel G, Duran Ö. Determining the knowledge of women and their attitudes regarding gynecological cancer prevention. Asian Pacific Journal of Cancer Prevention 2013; 14(10): 6055-6059.

20. Gözüyeşil E, Arı̈z Düzgün A, Ünal Aslan KS. Kadınların serviks kanserinden korunma ve erken tanıya yönelik tutumlarının değerlendirilmesi. STED 2019; 28(4):228-237.

21. Türkiye Cumhuriyeti Sağlık Bakanlığı Halk Sağlığı Genel Müdürlüğü, Türkiye Kanser İstatistikleri. 2018. 30-39. Ankara https:/hsgm.saglik.gov.tr/depo/birimler/kanser -db/istatistik/ ANA_rapor_2013v01_2.pdf. Erişim Tarihi: 27.09 .2020 .

22. Devesa SS. The burden of cancer in the elderly. In Treatment and Management of Cancer in the Elderly CRC Press; 2016. p.3152.

23. Doll KM, Meng K, Basch EM, Gehrig PA, Brewster WR, Meyer AM. Gynecologic cancer outcomes in the elderly poor: A population-based study. Cancer 2015;121(20): 3591-9.

24. Wingfield SA, Heflin MT. Cancer screening in older adults. Clinics in geriatric medicine 2016;32(1):17-33.

25. Perri T, Katz T, Korach J, Beiner ME, Jakobson-Setton A, Ben-Baruch G. Treating gynecologic malignancies in elderly patients. American Journal of Clinical Oncology 2015; 38(3): 